OPEN ACCESS

Edited by: Anabela Cachada, University of Porto, Portugal

Reviewed by: Elzbieta Antczak, University of Łódź, Poland Meghnath Dhimal,

Nepal Health Research Council, Nepal

*Correspondence: Silvia Fontan sfontan@unlam.edu.ar Matilde Rusticucci mati@at.fcen.uba.ar

Specialty section: This article was submitted to Land Use Dynamics,

a section of the journal

Frontiers in Environmental Science

Received: 22 January 2020 Accepted: 18 December 2020 Published: 12 February 2021

Citation:

Fontan S and Rusticucci M (2021) Climate and Health in Buenos Aires: A Review on Climate Impact on Human Health Studies Between 1995 and 2015.

Front. Environ. Sci. 8:528408. doi: 10.3389/fenvs.2020.528408

\section{Climate and Health in Buenos Aires: A Review on Climate Impact on Human Health Studies Between 1995 and 2015}

\author{
Silvia Fontan ${ }^{1 *}$ and Matilde Rusticucci ${ }^{2 *}$ \\ ${ }^{1}$ Department of Health Sciences, National University of La Matanza, San Justo, Argentina, ${ }^{2}$ Faculty of Exact and Natural Sciences, \\ CONICET, University of Buenos Aires, Buenos Aires, Argentina
}

In this review, seven pieces of research on climate variability and its impact on human health in Buenos Aires City between 1995 and 2015 were evaluated. The review highlighted continuities and ruptures in the methodology, variables, and statistics data of the research, considering their similarities and differences in the period of study and the methodology applied. Contributions, pending issues, and public policies on climate change challenges in the city aimed at improving living conditions were considered. Six studies contributed evidence on the relationship between climate and health and its impacts on the population; two studies suggested the development of early warning systems and one study is a preliminary approach.

Keywords: disease, heat waves, cities, human health, climate

\section{INTRODUCTION}

The climate is changing (Seneviratne et al., 2012) and this impacts on human health (Smith et al., 2014; Bárcena, 2020) directly, with an increase in the frequency of extreme events (cold and heat waves). This in turn creates an increased risk for vulnerable groups, such as children, the elderly, or those with previous pathologies (Semenza et al., 1996; Morabito et al., 2012). Extreme weather events can indirectly expand the area of disease vectors or reduce the availability of food (WHO, 2008). In Latin America, almost $80 \%$ of people live in cities (WHO, 2016), so it is very important to study the relationship between climate and health in an urban context, considering climate change projections (Barros et al., 2015) and policies (Magrin, 2015). Several studies analyzed the relationship of climate and weather events with health in Buenos Aires. This review focused on temperature events and their impact on human health between 1995 and 2015 in Buenos Aires City, and didn't include other events such as rain, extreme wind events, or air quality events. 
Considering climate as a determinant of health, future climate estimates $^{1}$ for the Metropolitan Area of Buenos Aires predicts increases in the frequency of floods and extreme events such as hail, heat and cold waves, air pollution, and increased plagues, pathogens, and vectors (Barros et al., 2015) The Metropolitan Area of Buenos Aires is currently the largest urban conglomerate in the country, Buenos Aires City with 2,900,000 inhabitants ${ }^{2}$ is part of a very large metropolitan area with almost $15,000,000$ people with high levels of inequality in living conditions between northern and southern communes (Martínez et al., 2019). The Institute of Statistics of the City calculates that 180 million passengers use the different means of transport monthly ${ }^{3}$. Land use in Buenos Aires developed a horizontal growth, from the best quality lands to those of inferior quality, with some areas even $6 \mathrm{~m}$ below sea level, which is unfavorable for urbanization (Pírez 2009; Vecslir and Ciccolella, 2011). Communes 2, 3, 5 , and 6 present the highest population density, in the central area of the city, and the south of the city presents lower density levels than central and north. (Figure 1). It can be seen that Communes 14 and 1 changed their densities between 2010 and 2015 (Figure 2).

Communes 2 and 14 (Recoleta and Palermo) have the highest rate of aging and communes 4,7 , and 8 have the lowest ratio of people over 65 for every one hundred under 15 . Buenos Aires' has seen an aging population since the 1970s, with $16 \%$ of the population currently over 65 years old, compared to $10.23 \%$ in Argentina (National Institute of Statistics and Censuses (INDEC), 2010). In regard to living conditions, $98.35 \%(1,065,159)$ of houses have a household connection to the public sewer network, while the remaining $1.65 \%$ of homes have excreta disposal in situ. In informal settlements, a lack of sanitation creates serious concerns; 68,776 of households are considered as Homes with Unsatisfied Basic Needs, while $73 \%$ count as inadequate housing and $25.6 \%$ as overcrowded.

Territorial expression of poverty is heterogeneous, (UNHabitat/WHO, 2010) concentrated in the southern part of the city in informal settlements. The northern region has the highest levels of living conditions (See Figure 3), the highest household per capita income, the lowest percentage of the population over 25 years old with only a primary school education, and the lowest percentage of the population covered only by public health. Southern communes present worse socio-economic indicators, with the lowest family household income per capita, the highest percentage of the population over 25 years old with incomplete

\footnotetext{
${ }^{1}$ According to Agencia de Protección Ambiental Scenario presented on the Second Plenary Meeting of the Interministerial Team. CABA. 2009. Action plan against climate change.

${ }^{2}$ Población de Buenos Aires. Año 14, número 25, abril de 2017 Publicación semestral de datos y estudios sociodemográficos urbanos editada por la Dirección General de Estadística y Censos (DGEYC) del Gobierno de la Ciudad de Buenos Aires https://www.estadisticaciudad.gob.ar/eyc/.

${ }^{3}$ Ministry of Interior and Transportation of the Nation https://www.argentina.gob. ar/transporte.

${ }^{4}$ Acknowledgment digital cartography by Adrian Iulita.
}

primary education as their highest level of education, and the highest percentage of the population covered by the public health system only. All these conditions impact on human health, and increase pressure on health systems, especially in a climate change scenario.

International literature $(\mathrm{WHO}, 2008)$ discussed 12 emerging diseases that are related to climate change, highlighting (Ballesteros et al., 2011) the following for Buenos Aires City:

- Vector-borne: dengue, yellow fever, leishmaniasis, malaria, and chagas.

- Rodent-borne: leptospirosis, hantavirosis, and viral hemorrhagic fevers.

- Water related diseases: diarrhea, gastroenteritis, hepatitis, helminthiasis, food toxinfections, and red tide.

- Acute and chronic respiratory problems associated with air quality.

This review compared seven pieces of research that used epidemiological data from the public health system, considering similarities and differences in topics:

Period of study: Since the Río Conference in 1992, climate change has been central to the international agenda, focusing on the mitigation of greenhouse gases and the adoption of adaptation strategies (IPCC, 2014; Magrin, 2014; Magrin 2015).

Methodology applied: Environmental health studies require an interdisciplinary approach, so decisions about methodology are crucial in order to compare data with different scales, such as climate data and epidemiological data (Berko et al., 2014)

This study has reviewed studies between 1995 and 2015, selected after searching in PubMed, Lilacs, and Google Scholar using the key words: BUENOS AIRES, HEALTH, and CLIMATE.

This review aimed to endorse evidence on the relationship between climate and health, and its impacts on populations.

\section{RESEARCH ABOUT CLIMATE AND HEALTH IN BUENOS AIRES CITY}

How did we choose the studies? There are different studies on the relationship between climate and health in Buenos Aires; the research selected in this review was supported by public institutions, used public data, focused on Buenos Aires City, and used weather data and health data. We didn't include studies supported by private funding.

Research selected, in the order they were published:

Association between weather conditions and the number of patients at the emergency room in an Argentine hospital (Rusticucci et al., 2002). The aim of this paper, published in 2002, was to study the relationship between hospital emergencies and weather conditions by analyzing summer 


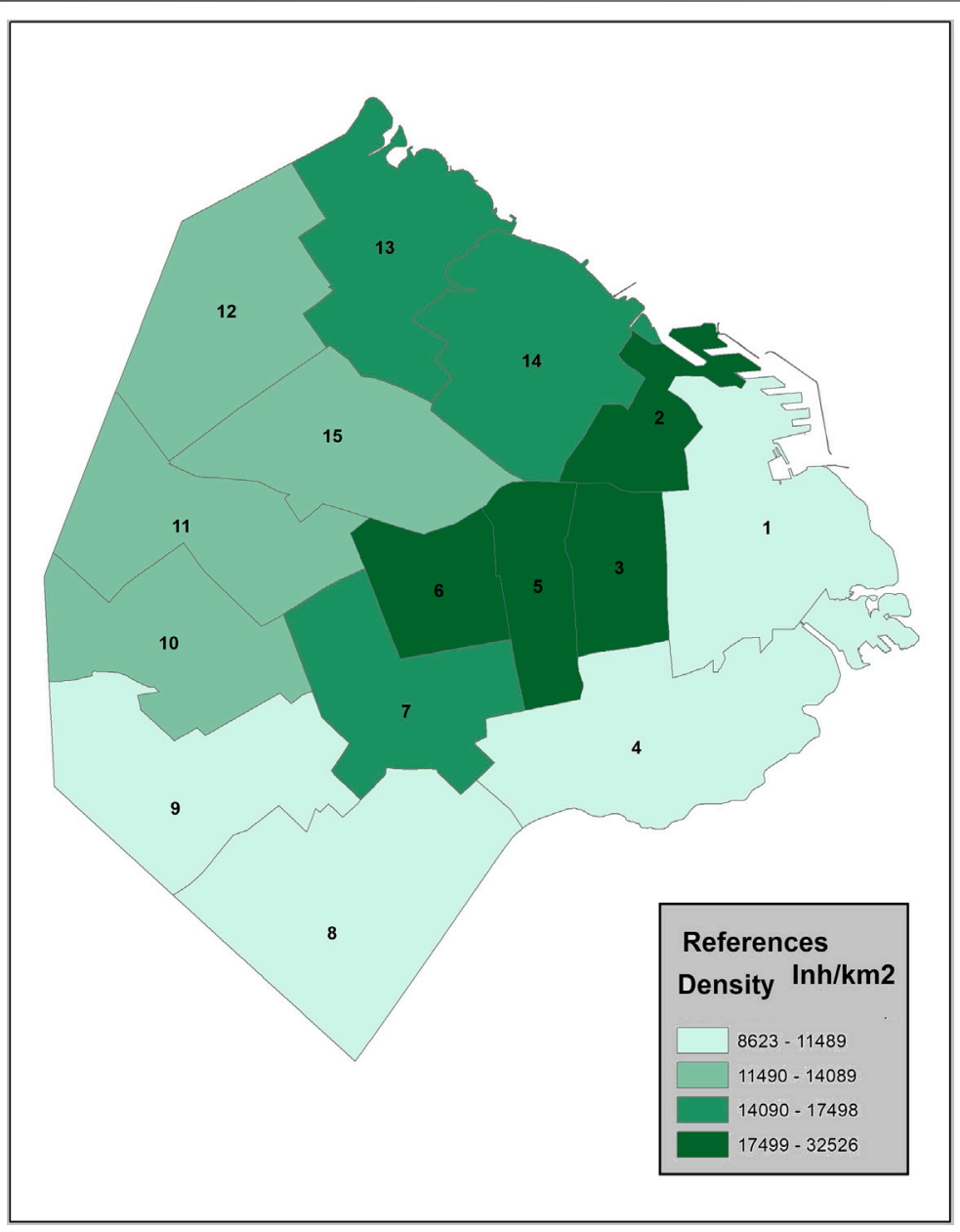

FIGURE 1 | Buenos aires. Density by commune $2010^{4}$.

and winter cases of patients requiring attention at the emergency room of a hospital in the city of Buenos Aires. Hospital data have been sorted into seven different diagnostic groups. They found a significant positive correlation with skin and allergy complaints with several day-lags observed between these three variables: maximum dew-point temperature, maximum temperature, and minimum air pressure. Peaks in admission were seen at days 1, 2, and 4, respectively. In winter there were significantly more cases of contusions and crushing, and more bone and muscle complaints on warm, dry days and on warm, wet days in the summer. Unless this was based only in two seasons, it was an exhaustive analysis.

Adaptation to climate change and health. Preliminary approach to Buenos Aires City (Ballesteros et al., 2011). This study was presented in August 2011; the objective was to highlight the behavior of four diseases associated with climate change in international literature. The period considered was 2007-2010. The diseases analyzed were Leptospirosis, Leishmaniasis, Dengue, and Acute Diarrhea, with data provided by the Ministry of Health of the City. This is a preliminary study, the period included is very short, it focused on diseases, and it did not use climate or extreme events data in the same period, so authors could not asses any relation between these phenomena. However, it was included here, because authors made an effort to include challenges to the public health system ahead of climate change adaptation. Association of monthly frequencies of diverse diseases in the calls to the public emergency service of the city of Buenos Aires during 1999-2004 with meteorological variables and seasons during 1999-2005 (Alexander 2013). Data were provided by the emergency system (SAME). Codes used to classify diseases in SAME are from the notes made by the physician who attended the emergency, and it was related to the Aeroparque Station of the National Weather Service (SMN). Several atmospheric variables were considered: atmospheric 


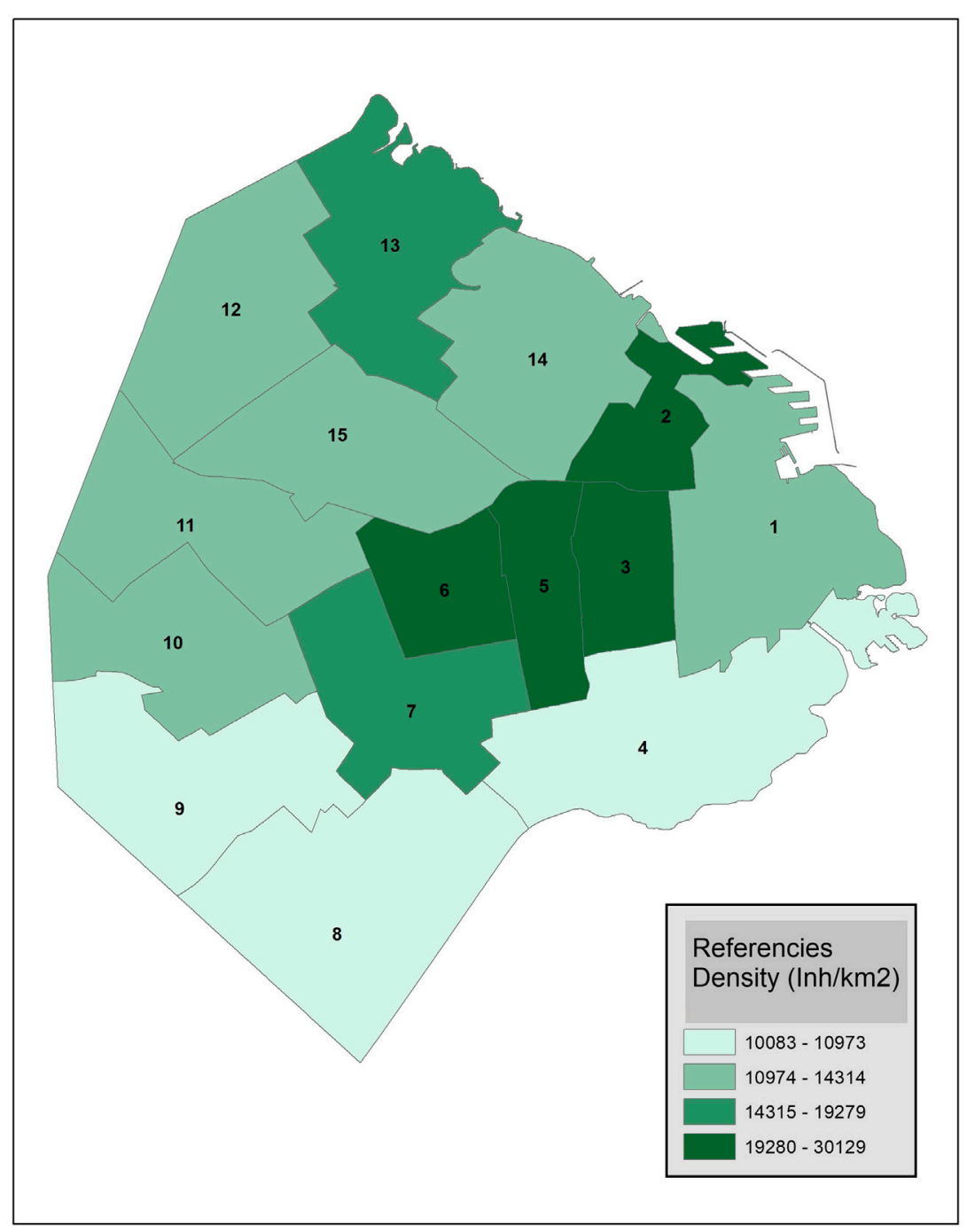

FIGURE 2 | Buenos Aires. Density, by commune, 2015.

sea level pressure, mean daily temperature, maximum temperature, minimum temperature, maximum apparent temperature, minimum wind chill temperature, accumulated precipitation, relative humidity, total heating degree days, and total cooling degree days. Thermal amplitude was determined as Tmax-Tmin. Apparent temperature and equivalent temperature were used to measure human discomfort due to combined heat and humidity. The diseases considered were ischemic heart disease, arrhythmia, heart failure, cardiopulmonary arrest, angina pectoris, psychiatric diseases, stroke, transient ischemic attack, and syncope. Codes used to classify diseases in SAME did not use the International Statistical Classification of Diseases and Related Health Problems 10th Revision ICD (10) $)^{5}$. They

${ }^{5}$ https://icd.who.int/browse10/2019/en divided 72 months into four seasons. To assess the associations between meteorological and health data they used Correlation analysis and calculated the linear correlation with Pearson's coefficient $r$.

They found a seasonal pattern with higher values in winter and lower values in summer for ischemia, with a peak value in June (winter). Occurrence seems to be related to season, rather than intensity of temperature values. Although SAME is only one part of the public health system, one million emergency calls received at SAME were analyzed. One limit of this approach is the time scale considered, because data was taken monthly, and weather changes occur in shorter periods, so it is possible some of the health impacts were not seen over this time scale.

Climate variability and its impact on health in four major south American cities 2005-2010 (Barboza et al., 2013). This research was financed by the Training Institute Seed Grant (TISG) of 


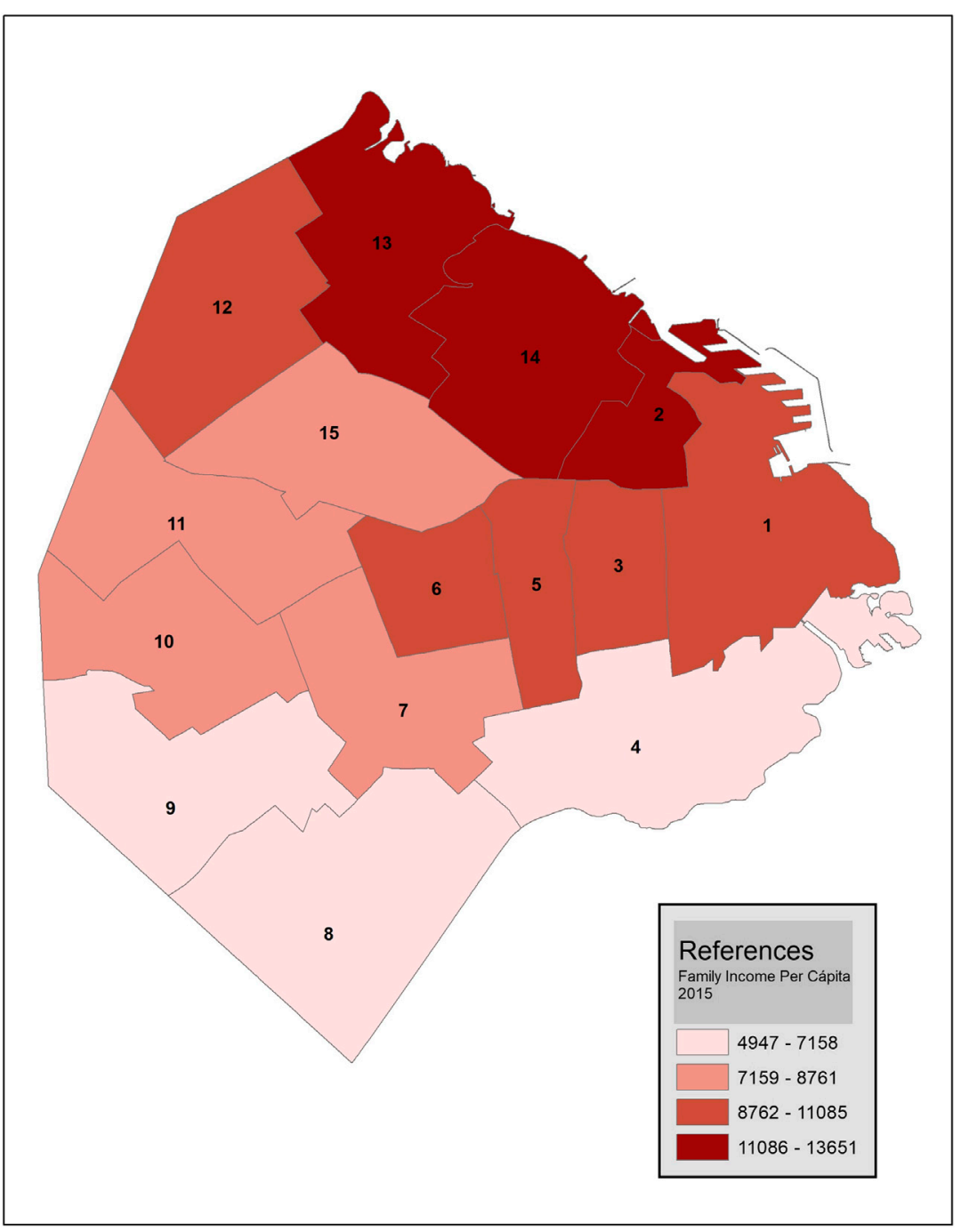

FIGURE 3 | Household per capita income (CPI) by commune. Buenos Aires City 2015.

the Inter-American Institute for Global Change (IAI). The relationship between extreme events (heat and cold waves) and their impacts on human health between 2005 and 2010 were analyzed. Cold and heat waves were determined by calculating percentiles 10 and 90 for maximum and minimum temperatures. In order to characterize the thermic environment, average daily temperatures and relative humidity values were used to calculate the biometeorological index of temperature and humidity (ITH). Heat and cold waves were classified as mild, moderate, and severe. Following international literature, climate-associated diseases were classified into communicable (CD) and noncommunicable diseases (NCDs) using ICD (10) codes.

$\checkmark$ CD included were diarrhea, viral hepatitis A, leptospirosis, dengue, acute upper respiratory tract infections, influenza, and acute lower respiratory tract infections. Data was provided by the Direction of Epidemiology of Ministry of Health. $\checkmark$ NCDs studied were hypertension, ischemic heart conditions, cerebrovascular diseases, and chronic lower respiratory tract diseases. Data was provided by the Direction of Statistics and Information in Health and the Epidemiology Department, both in the Ministry of Health.

Looking for an association between climate and health, exploratory techniques such as frequencies, measures of central tendency and dispersion, and bivariate correlation were applied.

The analysis of the reference period 1961-2010 has enabled the analysis of trends in the climate of Buenos Aires. An increase in minimum temperatures was observed; the minimum temperatures below the 10th percentile and the days with frost showed a significant tendency to decrease. Bronchiolitis (in children under the age of 2), pneumonia, 
and influenza were correlated with cold waves. The peak of bronchiolitis cases (in children under 2 years old) and influenza (in the general population) coincided with a cold wave in 2007. In occurrences of heat waves, data showed an increase in the number of cases of hypertensive diseases as the severity of the heat wave increased. In mild heat waves, the number of hypertensive diseases increased by $4.4 \%$, in moderate heat waves by $9.8 \%$ and in severe heat waves by $13.7 \%$. An association between Hepatitis $\mathrm{A}$ and heat waves was not observed.

Relation between mortality and extreme temperatures in Buenos Aires and Rosario (Almeira et al., 2016). This research analyzed the relationship between mortality and extreme temperature events in two major cities of Argentina, and was used as the basis to develop the Alert System for Heat Waves in both cities, which is essential in preventing negative health effects related to high temperatures. Weather data was provided by the Observatory Central Station. Heat waves were defined by Rusticucci (Rusticucci et al., 2016) as a period of three or more days with at least one of these values: minimum temperature over the 90th percentile, maximum temperature over the 90th percentile, or the coincidence of maximum and minimum temperature over the 90th percentile. It was found that both cities have a ' $U$ ' relationship between daily mortality and maximum, minimum, and apparent temperatures in the period of 2001-2012. Mortality that occurred during the heat waves (2001-2012) presented an excess between 20 and $80 \%$. Mortality increased significatively over $38^{\circ} \mathrm{C}$. The cause of death was not identified.

Analysis of mortality during heat wave on 2013-2014 summer in Argentina (Chesini et al., 2018). In this paper, authors analyzed the heat wave that occurred in December 2013; it was the largest and most intense heat wave registered in Buenos Aires since $1906^{6}$. This research compared mortality that occurred during the heat wave (HW) in 2013-2014 with mortality of the same period in the years 2010-2011, 2011-2012, and 2012-2013, which lacked HW. It was considered as the base to extend the Early Alert System for heat waves throughout the country. Mortality showed increases during the HW of the summer 2013-2014 in the overall rate, as well as in the specific death rates by age groups, sex, and cause of death. During the HW of December 2013, Buenos Aires was the jurisdiction of Argentina that presented with the highest number of cases with epidemiological evidence of causes of death (481 cases); it represented approximately half $(48.9 \%)$ of the deaths that occurred during that event. During the HW of December 2013, women's risk of dying was higher than men's (1.58 and

${ }^{6}$ National Weather Service began weather measures in 1906. www.smn.gob.ar http://www.smn.gov.ar/serviciosclimaticos, http://repositorio.smn.gob.ar/ bitstream/handle/20.500.12160/951/0060CL2018.pdf? sequence=1\&isAllowed=y.
1.34 respectively, both with statistical significance) meanwhile, in the HW of January, the increase in the risk of dying was more significant for men (Relative Risk $\mathrm{RR}=1.33$ Confidence Index CI 95\% = 1.12-1.58).

Mortality from heat waves in the city of Buenos Aires, Argentina (2005-2015) (Chesini et al., 2019) Authors used a time series designed with Generalized Additive Models (GAM) that allowed the link of mortality to days of heat waves throughout the period, controlling for time variables, mean temperature, and humidity. This study found that, during heat waves, risk of death increased by $14 \%$ (RR = 1.140; 95\% CI: 1.108-1.173) when compared to other days in the hot season. The increase occurred in both sexes and in all age groups, but children under 15 years old $(\mathrm{RR}=1.167 ; 95 \%$ CI: $1.019-1.335)$ and people over 84 years $(R R=1.201 ; 95 \%$ CI: 1.098-1.313) were more affected. The heat wave in December 2013 showed an increase of $43 \%(\mathrm{RR}=1.428$; 95\% CI: $1.399-1.457)$ in total daily deaths, increasing to $51 \%$ in elderly people ( 84 years or more) $(\mathrm{RR}=1.515 ; 95 \% \mathrm{CI}$ : $1.372-1.674)$ and $65 \%(\mathrm{RR}=1.647 ; 95 \% \mathrm{CI}: 1.367-1.986)$ for renal causes. The heat waves that occurred in Buenos Aires in the summer of 2013-2014 were analyzed in both studies (Ballesteros et al., 2011) (From here on Chesini) and (Ballesteros et al., 2011; Chesini et al., 2019) (From here on Abrutsky).

\section{Continuities and Ruptures}

The seven pieces of research we analyzed here focused on a period of time between 1995 and 2015; the area and population selected was Buenos Aires City. There were coincidences in some health events considered and meteorological variables, and all data was from public statistics. These similarities allow for their comparison. Six studies were developed by interdisciplinary groups of researchers, while in one the authors are meteorologists. Ballesteros et al., 2011 (From here on Ballesteros) is a preliminary approach and did not assess meteorological data.

\section{What About Methodology?}

Meteorological variables were considered and the literature cited coincided. This may be because of the role played by the World Meteorological Organization, which established standards and tools a long time ago. Weather data was provided by the National Weather Service. There are two official weather stations in Buenos Aires; Central Observatory station was used in four studies, while the research developed by Barboza et al., 2013 (From here on Barboza) also included Aeroparque Station and Alexander, 2013 (From here on Alexander) used data from the Aeroparque station only.

There are many ways to define an extreme event, and it was a topic of discussion in four studies. Nevertheless, all studies agreed that an extreme event lasts for at least three days. Alexander, Almeira et al., 2016 (From here on Almeira) and Barboza took into account human comfort, so they 
included humidity as a factor. They also agree on the analysis of anomalies. Barboza and Chesini focused on the relation between extreme temperature events and human health over a short period. There is a coincidence on the impact of HW on elderly people, but Barboza used morbidity data and Chesini used mortality data.

To analyze temperature values and health, Alexander and Almeira focused on trends and chose longer periods of time; they included extreme temperature. Only Rusticucci et al (From here on Rusticucci) considered weather synoptic situations.

\section{Human Health Data}

Almeira and Chesini used mortality data. It is a solid database, so it can be used with methodology and tools in order to achieve high levels of confidence. Ballesteros, Alexander, and Barboza studied morbidity. Diseases were coded with ICD (10) in four of the studies. Data from SAME was coded in a different way, but diseases included were coincident. Rusticucci grouped diseases with their own criterium.

The impact of climate variability may be different in some groups, such as children and older people, or in case of a previous disease, such as diabetes, obesity, or hypertension, so it is highly relevant to asses vulnerable groups. Barboza and Chesini studied the relationship of extreme temperature events in age groups and found a significant correlation between them.

\section{Time Scales}

It is difficult to organize information from different sources, collected with different frames and designed with different objectives. How did these researchers make their weather and health data compatible? Each group of researchers made their own decision in order to categorize weather and health data. Ballesteros only used annual morbidity data, while Alexander made a monthly average. In the case of Barboza, the authors made an extra effort in order to compare cities located in four different countries; they used epidemiological weeks as time scales for data, weather, and health. Almeira, Rusticucci, and Chesini used daily data, which was possible because mortality and attendance at the emergency room are registered daily.

\section{Geographical Scale}

Climate variability is a regional phenomenon, and its impact is not related with geopolitical borders. How did researchers compare Buenos Aires with other areas or other populations? This issue was considered in three papers: Barboza developed their research for other South American cities; Almeira, who compared with Rosario, and Chesini included 16 other provinces in Argentina. Almeira and Chesini expanded their results and they became the basis for the Early Alert System, first in Buenos Aires, Rosario, and later on for the whole country. Both experiences show the importance of dialogue in the interface between academicians and stakeholders, as well as the importance of building knowledge interdisciplinarily, and using public statistics.

\section{CONCLUSION}

The differences in living conditions in the 15 communes of Buenos Aires City means different methods and resources are available to offse the impact of extreme events. Two of the studies analyzed here considered risk in different age groups, but there was no consideration of these differences inside the city. However, these risk groups were defined based on age alone, and other categories of risk were not considered.

The knowledge that climate impacts on human health ${ }^{7}$ should be supported by studies and validation criteria that combine the physical aspect of climate, which takes place in the atmosphere, with biological and epidemiological phenomenon, which occur throughout population groups.

Six studies contributed evidence on the relationship between climate and health and its impacts on populations; two of them were used to develop early warning systems and one study is a preliminary approach.

The papers reviewed here show that the public sector (such as academia, the Ministry of Health, and the Climate Service) can be benefitted by climate research, and it would be very interesting to analyze if these results were taken into account in urban planning, public policies, or adaptation planning on climate change. Studying the impact of temperature on human health enables the creation of new approaches and methodologies to investigate the macromicro relationship between climate and health in order to improve social policies and climate change adaption measures.

\section{AUTHOR CONTRIBUTIONS}

MR PhD in Atmospheric Sciences at the Universidad de Buenos Aires (UBA). Professor at UBA. Principal Researcher CONICET. IPCC AR6 WG2 Lead Author. (AR5 WG1 CLA, and SYR, AR4 LA and SR4 SYR LA) MR: Her main research fields are: Climatology of South America, focused particularly on extreme events; Climate change and long term variability in observed and modelled extreme events, data consistency and quality; Climate impact on human health; Evaluation of climate models; Projections of extremes; Associated air and ocean circulation patterns and teleconnections; Andean Climate. SF: Sociologist. Specialist, Professor and Researcher at Universidad Nacional de la Matanza. Departamento de Ciencias de la Salud. Her main research field is Climate and health in cities.

${ }^{7} \mathrm{https} / /$ www.paho.org/salud-en-las-americas-2017/?post_type=post_t es\&p=310\&lang=es. 


\section{REFERENCES}

Alexander, P. (2013). Association of monthly frequencies of diverse diseases in the calls to the public emergency service of the city of Buenos Aires during 19992004 with meteorological variables and seasons. Int. J. Biometeorol. 57, 83-90. doi:10.1007/s00484-012-0536-8

Almeira, G., Rusticucci, M., and Suaya, M. (2016). Relación entre mortalidad y temperaturas extremas en Buenos Aires y Rosario. Meteorológica 41 (2), 65-79.

Ballesteros, I., Fontan, S., and Grebnicoff, A. (2011). Adaptación al cambio climático y salud. Abordaje preliminar para la ciudad de buenos aires. Buenos Aires: Acta Bioquímica Clínica Latinoamericana.

Barboza, G., Martínez, M., Frasco, L., Fontán, S., Chesini, F., González, E. C., et al. (2013). Climate variability and its likely impact in four mayor south-american cities: Buenos Aires, Manus, Montevideo, Salto and Santiago. Buenos Aires, Argentina: Ministry of Health.

Bárcena, A. (2020). y otros, La emergencia del cambio climático en América Latina y el Caribe: ¿seguimos esperando la catástrofe o pasamos a la acción? Libros de la CEPAL. N 160 (LC/PUB.2019/23-P). Santiago, Chile: Comisión Económica para América Latina y el Caribe (CEPAL)

Barros, V. R., Boninsegna, J. A., Camilloni, I. A., Chidiak, M., Magrín, G. O., and Rusticucci, M. (2015). Climate change in Argentina: trends, projections, impacts and adaptation. WIREs Clim Change. 6 (2), 151-169. doi:10.1002/ wcc. 316

Berko, J., Ingram, D. D., Saha, S., and Parker, J. D. (2014). Deaths attributed to heat, cold, and other weather events in the United States, 2006-2010. National health statistics reports. Hyattsville, MD: National Center for Health Statistics, 76.

Chesini, F., Abrutzky, R., and de Titto, E. (2019). Mortalidad por olas de calor en la ciudad de Buenos Aires, Argentina (2005-2015). Cadernos de Saúde Pública 35 (9), 1-11. doi:10.1590/0102-311X00165218

Chesini, F., Fontán, S., González Morinigo, E. C., Herrera, N., Savoy, F., Skansi, M. M., et al. (2018). "Analysis of mortality during heat waves in 2013-2014 summer in Argentina first global forum for heat and health," in Proceedings of the First Global Forum for Heat and Health. Hong Kong, China, December 17-20, 2018.

Fontan, S., and Ballesteros, I. (2013). Impact of climatic variations on the health of older adults in urban areasJornada: habitat saludable para el adulto mayor. UNLAM ADAAIH.

IPCC (2014). "Climate change 2014: impacts, adaptation, and vulnerability." in Part A: global and sectoral aspects. Contribution of working group II to the fifth assessment report of the intergovernmental panel on climate change. Editors C. B. field, V. R. Barros, D. J. Dokken, K. J. Mach, M. D. Mastrandrea, T. E. Bilir, et al. (Cambridge, United Kingdom and New York, NY: Cambridge University Press), 1132

Magrin, G. (2014). "Central and south America" Climate change 2014: impacts, adaptation, and vulnerability. in Volume II: regional Aspects, "Latin America", climate change 2007: impacts, adaptation, and vulnerability. Editor V. Barros y otros (Cambridge, United Kingdom: Cambridge University Press).

Magrin, G. (2015). Adaptación al cambio climático en América Latina y el Caribe. Documentos de Proyectos (LC/W.692). Santiago, Chile: Comisión Económica para América Latina y el Caribe (CEPAL).

Martínez, R., Lo Cascio, J., and Leone, J. (2019). Brechas socioeconómicas al interior de CABA. Una propuesta desde la medición multidimensional de la pobreza. Cuadernos de Investigación. Serie Economía, [S.l.] 7, 70.

Morabito, M., Profili, F., Crisci, A., Francesconi, P., Gensini, G. F., and Orlandini, S. (2012). Heat-related mortality in the Florentine area (Italy) before and after the exceptional 2003 heat wave in Europe: an improved public health response? Int. J. Biometeorol. 56 (5), 801-810. doi:10.1007/s00484-011-0481-y

National Institute of Statistics and Censuses (INDEC) (2010). National population, household and housing census 2010REDATAM database: methodological aspects, Buenos Aires. Buenos Aires, Argentina: National Institute of Statistics and Census. Available at: http://www2.cedom.gov.ar/es/legislacion/ normas/leyes/ley4237.html1/2.

Pírez, P. (2009). Buenos aires, la formación del presente. Organización Latinoamericana y del caribe de centros históricos. Quito.

Rusticucci, M., Bettolli, M. L., and Harris (2002). Association between weather conditions and the number of patients at the emergency room in an Argentine hospital. Int. J. Biometeorol. 46, 42-51. doi:10.1007/s00484-001-0113-z

Rusticucci, M., Kyselý, J., Almeira, J., and Lhotka, G. (2016). Long-term variability of heat waves in Argentina and recurrence probability of the severe 2008 heat wave in Buenos Aires. Theor. Appl. Climatol. 124 (3-4), 679-689. doi:10.1007/ s00704-015-1445-7

Semenza, J. C., Rubin, C. H., Falter, K. H., Selanikio, J. D., Flanders, W. D., Howe, H. L., et al. (1996). Heat-related deaths during the July 1995 heat wave in Chicago. N. Engl. J. Med. 335 (2), 84-90. doi:10.1056/ NEJM199607113350203

Seneviratne, S. I., Nicholls, N., Easterling, D., Goodess, C. M., Kanae, S., Kossin, J., et al. (2012). "Changes in climate extremes and their impacts on the natural physical environment," in Managing the risks of extreme events and disasters to advance climate change adaptation. A special report of working groups I and II of the intergovernmental panel on climate change (IPCC). Editors C. B. field, V. Barros, T. F. Stocker, D. Qin, D. J. Dokken, K. L. Ebi, et al. (Cambridge, UK, and New York, NY: Cambridge University Press), 109-230.

Smith, K. R., Woodward, A., Campbell-Lendrum, D., Chadee, D. D., Honda, Y., Liu, Q., et al. (2014). "Human health: impacts, adaptation, and co-benefits," in Climate change 2014: impacts, adaptation, and vulnerability. Part A: global and sectoral aspects. Contribution of working group II to the fifth assessment report of the intergovernmental panel on climate change. Editors C. B. field, V. R. Barros, D. J. Dokken, K. J. Mach, M. D. Mastrandrea, T. E. Bilir, et al. (Cambridge, United Kingdom and New York, NY: Cambridge University Press), 709-754.

UN-Habitat/WHO (2010). Hidden cities: revelation and overcoming health inequities in urban contexts. Geneva, Switzerland: WHO.

Vecslir, L., and Ciccolella, P. (2011). Relocalización de las actividades terciarias y cambios en la centralidad en la Región Metropolitana de Buenos Aires. Rev. Geogr. Norte Gd. 49, 63-78. doi:10.4067/S0718-34022011000200005

WHO (2008). Climate change and human health: risks and responses: summary updated 2008. Geneva, Switzerland: WHO.

WHO (2016). Global report on urban health: equitable, healthier cities for sustainable development. Geneva, Switzerland: WHO.

Conflict of Interest: The authors declare that the research was conducted in the absence of any commercial or financial relationships that could be construed as a potential conflict of interest.

Copyright (c) 2021 Fontan and Rusticucci. This is an open-access article distributed under the terms of the Creative Commons Attribution License (CC BY). The use, distribution or reproduction in other forums is permitted, provided the original author(s) and the copyright owner(s) are credited and that the original publication in this journal is cited, in accordance with accepted academic practice. No use, distribution or reproduction is permitted which does not comply with these terms. 